\title{
The Bamboo Business in Tasikmalaya, Indonesia, During the COVID-19 Pandemic
}

\author{
Ary Widiyanto ${ }^{1, *}$, Suhartono Suhartono ${ }^{1}$, Marcellinus Utomo ${ }^{2}$, Idin Saepudin Ruhimat ${ }^{2}$, Tri Sulistyati \\ Widyaningsih 2,3, Maria Palmolina 2, Eva Fauziyah², Sanudin Sanudin ${ }^{2}$ \\ 1 Department of Environmental and Forest Resource, Research and Development Institute of Agroforestry \\ Technology, FORDA, MoEF, Indonesia \\ 2 Department of Socio-Economic, Research, and Development Institute of Agroforestry Technology, \\ FORDA, MoEF, Indonesia \\ ${ }^{3}$ Leadership and Policy Innovation Program, the Graduate School, Universitas Gadjah Mada, Yogyakarta, \\ Indonesia \\ *Correspondence author: ary_301080@yahoo.co.id; Tel.: +62-813-8855-8884
}

\begin{abstract}
Globally, various sectors were adversely affected by the emergence of the COVID-19 pandemic. Therefore, this study aims to determine the economic condition of bamboo craftsmen in Mandalagiri Village, Leuwisari District, Tasikmalaya Regency, West Java Province, Indonesia. This is an in-depth research with data obtained by interviewing 35 bamboo craftsmen with various products and production scales. The results showed that craftsmen were not economically affected by the pandemic rather by the central governmentstipulated regulation on social distancing, which led to their inability to transport their product from Tasikmalaya to Jakarta and other regions. However, since the government lifted the ban, their income has increased by an average of $2 \%$. The result further showed that the main factor that keeps craftsmen from being negatively affected by the pandemic is the increasing online market demand supported by the availability of raw materials and the ability to adapt to various new model products. Other factors linked to the national market and products answer the demand of the modern market in the cities. Meanwhile, the main factors that positively affect the craftsmen's income are age and marital status.
\end{abstract}

Keywords: bamboo SME; COVID-19 pandemic; economic condition; craftsmen; Tasikmalaya

\section{Introduction}

The Indonesian government implemented various policies, such as large-scale social distancing, self-isolation, and travel restriction to block human-to-human transmission of the coronavirus (Directorate General of Disease Prevention and Control, 2020; Ministry of Health, 2020). This led to the closure of schools, offices, and public places to avoid mass gathering and prevent further transmission. According to Djalante et al. (2020) and Victoria (2020), these policies significantly impact Indonesia's economy because of the drastic change in the consumption pattern. Indonesia's economy relies on agriculture, industry, and services with $13.7 \%, 41 \%$, and $45.4 \%$ GDP per sector, respectively (Indexmundi, 2019). In April 2020, the Minister of Finance explained that the adversity on the tourism sector, work termination, and the decreasing value of imports and export aggravated the Indonesian economy. The minister further stated that Java Island, which contributes approximately $57 \%$ to the Indonesian economy, has the highest number of coronavirus cases. Kencana (2020) stated that this condition provides a significant impact on economic prospects and community activities. According to Widyar (2020) in Supriyatno (2020), the pandemic is likely to impact on Indonesian economy until 2021 continuously.

One of the backbones for the Indonesian economy and other developing countries is a smallmedium enterprise (SME). Many authors argue that the pandemic has caused several negative impacts for the SME (Abbasov \& Alizada, 2016; Baker \& Judge, 2020; Feranita, et al., 2020; Lutfi et al., 2020; OECD, 2020; Rosavina et al., 2019; Setiawan, 2020; Sugiri, 2020). OECD (2020) stated that the negative impact faced by micro-small-medium enterprises today is more significant than when 
the global economic crisis hit in 2008. However, Rosavina et al. (2019) reported that SMEs are more resilient to sudden shocks. In addition, Narula (2020) stated that the rural economy in which most SMEs are located is less severely affected than the urban economy. For example, Roman and Grudzień (2021) stated that agro-tourism in rural areas remains profitable during the pandemic because people choose places with few visitors.

SMEs faced many challenges, such as logistical disruptions, labor mobility regulations, and a decline in market demand during the pandemic (Dai et al., 2021). Liu \& Cheng (2018) stated that SMEs are more vulnerable to crises because they have lower capital reserves, less inventory, and lower productivity than larger businesses. This condition is compounded by the lack of digitalization, technology adoption, and limited online individual and family-owned SMEs (Bartik et al., 2020). According to Caballero-Morales (2021), the challenges faced are primarily due to more cash flow to retain workers, pay rent, and make infrastructure investments.

Lu et al., (2021) stated that China, as the first country to be hit by the pandemic, had a decline in SMEs due to their inability to continue work and production. The industrial sector is primarily affected by poor logistics, inadequate supply chain management, the use of online services for wholesale and retail trading, etc. Dimson et al. (2020) stated that approximately 70 percent of more than 2,200 companies in France, Germany, Italy, Spain, and the UK experienced decreased in income due to the pandemic with various side effects, such as fears of defaulting loans, laying off employees, and project cancellation. It is also associated with the inability for businesses to last more than 12 months despite receiving assistance from the government in tax breaks and payments for laid-off employees.

One of the most effective strategic responses to crises is innovation (Caballero-Morales, 2021; Wenzel et al., 2020). The ability to innovate and external input through the benefits of the network is an essential determinant of small businesses (Forsman, 2011). According to Hernández-Espallardo and Delgado-Ballester (2009), innovation is essential to improve company performance.

Markovic et al. (2021) stated that SMEs tend to choose the right business partners to realize appropriate innovations during the pandemic. The selection of external partners is an essential factor in increasing open business-to-business innovation management (Bigliardi \& Galati, 2016). Furthermore, collaboration built with competitors, distributors, suppliers, research institutions is needed (Bagherzadeh et al., 2021). Markovic et al. (2021) stated that collaboration with customers provides the necessary resources to develop innovations suitable for the end market.

As a home industry, bamboo handicrafts are closely related to technology that helps facilitate productivity. Changes that occur in an industry have an impact on people in the vicinity of the industrial area. Ibrahim \& Nurdian (2020) stated that Covid-19 initially impacted decreasing the income of bamboo craftsmen in Antirogo Village, Jember Regency. However, the use of social media (e-commerce) increased the sales of bamboo handicrafts, and products rate returned to normal. Therefore, the presence of the pandemic changed the marketing pattern of bamboo handicrafts, which from traditional to digital.

However, market demand for this handicraft is still relatively high in some centers, even though the procurement of raw materials and product designs is still traditional, including woven bamboo crafts in Heuluet, Leuwimunding Majalengka (Barnawi, 2020). Small and medium-sized industries that employ the services of rural communities are still needed in accelerating the economic progress of the village (Darajat, 2015).

Innovation is also carried out using business strategies through the adoption of digital transformation to maintain its continued existence until the post-pandemic era (Bai et al., 2021). The digital transformation that is prioritized is digital payments using mobile money, which needs the support of the government, supply chain partners, and the community.

Several studies related to the impact of the pandemic on human life have been conducted. However, this research discusses the pandemic's impact on health, education, tourism, and the economy in general. It specifically discusses the impact of the pandemic on the forest industry, especially SMEs engaged in processing non-timber forest products (NTFPs), such as bamboo in Indonesia. 
One of the regencies in Indonesia that relies on bamboo-based SMEs for their rural economic development is Tasikmalaya. Bamboo-based SMEs create more than 17,000 job opportunities, with more than $90 \%$ concentrated in rural areas in Tasikmalaya Regency. McKibbin \& Fernando (2020) stated that due to the unprecedented disaster in the last of the pandemic and the unclear economic effects, it is essential to determine the impact(s) of the pandemic on the economic conditions of the bamboo artisans in Tasikmalaya Regency. This study utilized the recovery approach, therefore, the finding is an important reference for policymakers in setting appropriate policy interventions.

\section{Materials and Methods}

\subsection{Data Collection}

Data were collected in February and March 2021 from Mandalagiri village, one of the biggest bamboo craft industry centers in Tasikmalaya Regency, West Java Province, Leuwisari subdistrict(Lubis, 2008; Sakri, 2009). In Mandalagiri Village, there are 10 units of bamboo business with 97 of 430 craftsmen in Leuwisari sub-district (Statistic Indonesia of Tasikmalaya Regency, 2020). According to Gerring (2008), the bamboo business in this regency is typical, therefore, the findings are relevant to the wider population.

This research employed the purposive sampling method in the respondent selection process to guarantee that each bamboo product is represented (Tongco, 2007). Due to the data reliability issue, the authors failed to limit the minimum and maximum number of respondents until at the $35^{\text {th }}$ respondent, when saturation was achieved (Fusch \& Ness, 2015; Guest et al., 2006). Data were collected using in-depth interviews and questionnaires consisting of information on household socio-economic conditions before and during the pandemic, business activities of the bamboobased business, and impacts of the virus on artisans. Government documents such as regulations related to COVID-19 responses are gathered online.

\subsection{Analysis}

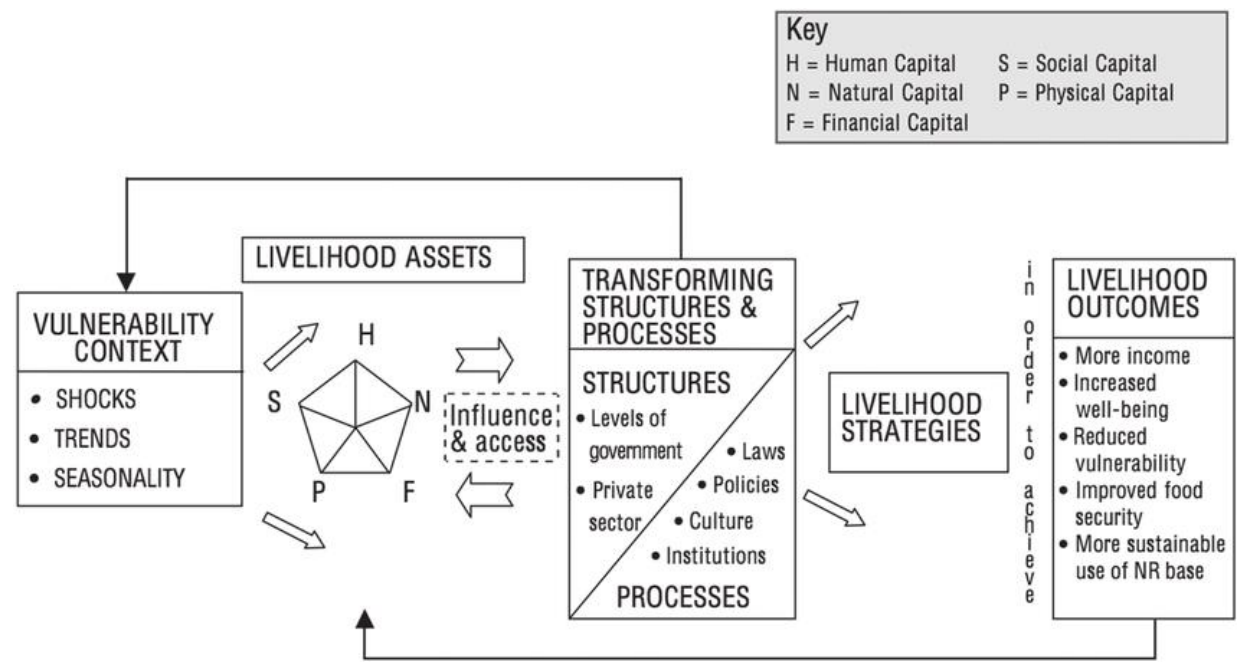

Figure 1. Sustainable Livelihoods Framework (DfID, 1999)

The data collected were analyzed using the descriptive statistics and correlation analysis, which was carried out to imply the factor(s) influence artisans' income. The dependent variable $(Y)$ is income, and the independent variables are age $(x 1)$, marital status $(x 2)$, gender $(x 3)$, education background $(x 4)$, side job ( $x 5)$, working experience $(x 6)$, and the number of family member $(x 7)$. Bowen's (2009) document analysis process was used to analyze the government's documents. Sustainable livelihoods analysis (SLA) (Department for International Development UK, 1999), which focuses on human, physical, natural, financial, and social capitals, is used to determine the pandemic's effect on bamboo artisans, as shown in Figure 1.

This concept of five capitals is commonly used to assess the capitals owned by the society and arrange the set of actions needed to create more sustainable livelihoods. This is a common approach 
applied by donors in conducting action research and rural development programs. Many social studies on community development were also used in proposing livelihood strategies.

\section{Results and Discussion}

\subsection{Respondent Characteristic and Bamboo Business Profile}

Respondents came from one of the largest bamboo handicraft centers in Tasikmalaya Regency, namely the craft center Leuwisari. Of the 35 respondents, two came from Ciawang, and the remaining 33 were from Mandalagiri, with both villages located in Leuwisari District, Tasikmalaya Regency. In terms of gender, 30 respondents were men, and 5 were women with varying socioeconomic conditions. The average length of education is 7.7 years, equivalent to Grade 2 in Junior High School. Almost all respondents only worked as a bamboo craftsmen, with only 4 having additional jobs. The results showed that the mean age of the respondents was 45.1 years, with 32 (91.4\%) under the age of 64, which is the productive age according to the Central Statistics Agency.

The average business experience was 17.1 years, with the lowest and highest being 1 and 40 years, respectively. Of the 35 respondents, only 9 had a business experience of fewer than 10 years. Long business experience showed that the community in the Leuwisari sub-district, especially in the village of Mandalagiri, has carried out bamboo handicraft business for a long time. Some respondents state that this work has been carried out from one generation to another in line with the research carried out by Sopandi (2017), Widyaningsih et al. (2020), Sakri (2009), Setiawan (2010), and Murti (2018). This is evidenced by the fact that $11(31.4 \%)$ respondents are under 40 years old, and the youngest is 18 years old.

Of the 35 respondents, only 4 joined the Cahaya Mandiri and Lestari Bambu craftsmen groups. The owners' also known as prominent artisans, ordered mainly semi-finished products from individual SMEs. Therefore, irrespective of these individual artisans' inability to join the group, they still benefit from the business partnership. The prominent artisans already have regular customers in the Cikini area, Jakarta, and the most saleable products are parcel holders and gift boxes.

The form of working relationship between craftsmen as members of the group and those outside was selling off. Sometimes, those in the medium/large category provided capital for their subordinates in a hectic market. In addition, they had business and social relationships between neighbors and relatives.

The working relationship in bamboo craftsmen shows a pattern of associative social relations between them, which were interrelated and strong based on relationships that need and benefit each other. They are related to business activities and neighboring hoods. Astuti (2012), stated that in addition to enhancing and maintaining the stability of their household economy, the working relationship also fosters solidarity in the form of mutual help, and trust.

The strategy carried out by these bamboo craftsmen leads to the exchange of various transactions with the ability to make an investment in a subsystem. It also shows the strategies used by the medium-scale craftsmen to maintain power and control over the small-scale craftsmen. This working relationship is one of the factors that make bamboo handicrafts survive and the ease of raw materials and market demand.

The products produced by craftsmen vary significantly, with approximately 15 semi-finished products (woven, assembled boxes) and 13 finished ones. Details of products, manufacturing quantities, sales results, and profits are shown in Figure 2. Among the many types of bamboo handicrafts produced by the people of Mandalagiri Village, container products and various deliveries were mostly produced during the pandemic. 


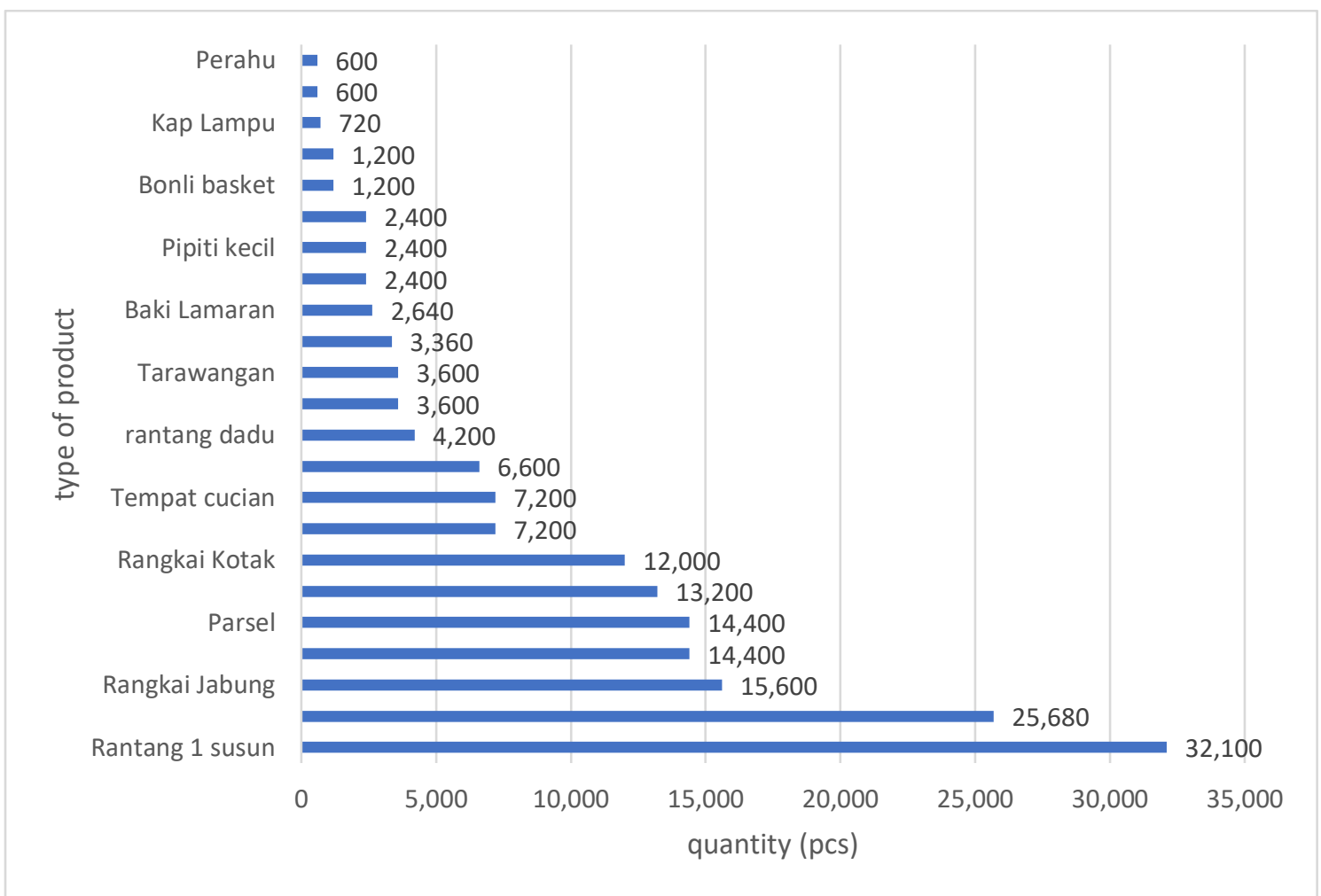

Figure 2. Type and quantity of bamboo handicraft production in Mandalagiri Village in 2020

In general, the bamboo handicraft business actors in Mandalagiri Village are still in the livelihood activity category without a micro-enterprise. There are only three business actors that fall into the small dynamic enterprise category. These individual entrepreneurs are essential in SME's development (Liñán et al., 2019), with their ability to determine opportunities (Kirzner, 2009) and manage workers (Bell \& Stellingwerf, 2012). According to Singh \& Belwal (2008) they are also able to overcome challenges related to social disparities, economic growth, and job creation. The individual values of an entrepreneur are important in all cases (Spence et al., 2011).

Bamboo handicrafts in Leuwisari Subdistrict are attached to the daily life of the community, both men and women, parents and young people. They are used to make basic models of the crafts, with finishing activities carried out by skilled craftsmen. One of the businessmen in the Tasikmalaya area stated that finishing activity for several special requests were carried out in their workshops, and the craftsmen only made semi-finished goods.

The bamboo handicraft business by the people of Mandalagiri Village, Leuwisari District, has been going on for a long time and has been passed down from one generation to another. This business still exists today, and it is not affected by the modernization of various tools made of plastic or other mining materials. During the pandemic in early 2020, the bamboo handicraft business increased sales, thereby generating high profits. One type of handicraft product can generate profits of $50 \%$ of the product's value on average. This count has not been deducted by the value of the labor, although it indicates that working as a bamboo craftsman is more profitable within the region.

During the pandemic, jobs as bamboo craftsmen were increasingly in demand by the people of Mandalagiri Village, thereby indicating better competitiveness than other business sectors in the area. According to Rosmadi (2021), apart from being profitable, these businesses also have comparative and competitive advantages used to maintain the sustainability of micro-businesses. This is similar to the research carried out by Rosyada \& Wigiawati (2020), which stated that pekalongan batik micro-business actors implemented strategies to enrich product types, innovation, and business creativity during the pandemic.

The many types of handicraft products manufactured by the people of Mandalagiri Village indicate the continuous use of innovation strategy and business creativity. However, only quite a few were produced during the pandemic of these numerous types, such as bushels, set boxes, rangkai jabung, and parcels. The basket is the type of handicraft commonly produced during the 
pandemic. The high demand for these goods is related to the change in consumption behavior of people in urban areas due to the pandemic.

Currently, there is a significant increase in demand by the people of Mandalagiri Village. These conditions indicate that working as a bamboo craftsman within the regions is more profitable than outside due to motivation. Economichypothesis stresses the extrinsic drivers of decision-making in specific item product prices and input costs. The individualcontext refers to intrinsicmotivation for decision-making(Ingram et al., 2013). It relates to individual and social conditions in which the farmer operates, such as knowledge, skills, power, and attitudinal and psychological dimensions (Greiner, 2015). Another craftsman's motivation is to continue a business pioneered by parents or other family members with craftsman skills. This woven product is a functional handicraft category because it is used to support daily life.

Bamboo crafts have comparative and competitive advantages. Simbolon (2019)stated that bamboo handicrafts have Trade Specialization Index between $0.01-0.8$. Therefore, they are included in the category of growth or export expansion stage. Hence, the bamboo handicraft business in Mandalagiri Village, Leuwisari District, Tasikmalaya Regency still needs to be developed, although it requires several strategies. Benton et al., (2011) reported that bamboo crafts need workers to have high creativity, skill, and adequate technology. Unfortunately, Indonesia has not yet focused on training or the correct understanding of the advantages of bamboo in the world market. Therefore, the government or society has not completely developed Indonesian bamboo products (Adil et al., 2014).

\subsection{Bamboo Business Performance during the COVID-19 pandemic}

As previously stated in the section on general conditions, all respondents made the bamboo handicraft business their main source of livelihood. However, only four people have additional jobs, which contribute to about $1.2 \%$ of total income.

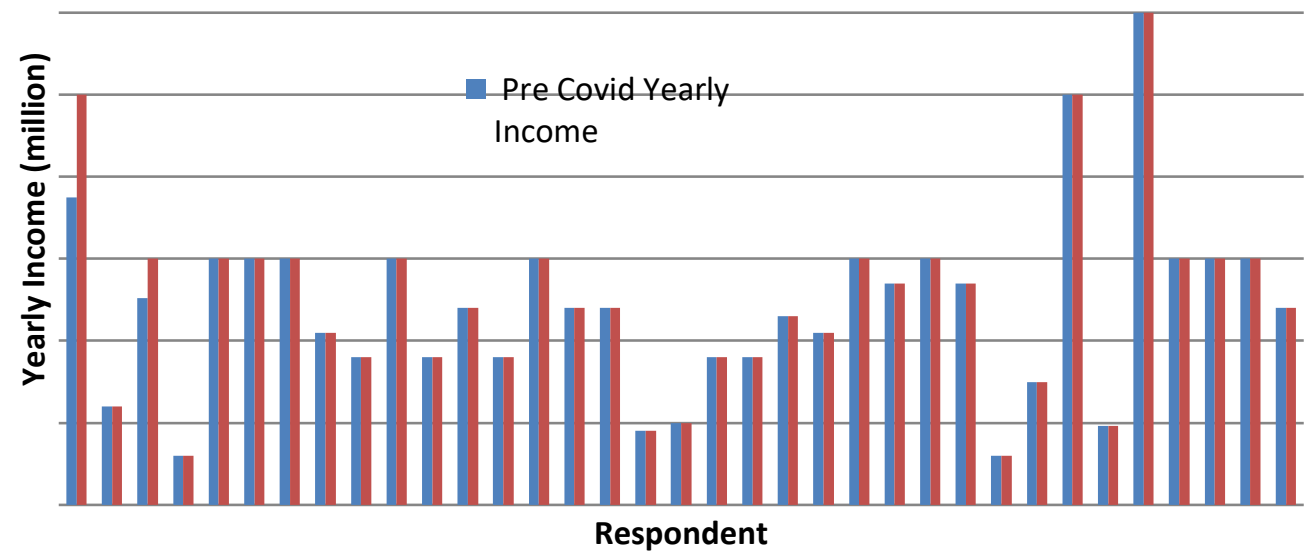

Figure 3. Annual income before and after COVID-19 pandemic

The figure above shows that during the pandemic, the income of craftsmen increased by an average value of $2 \%$. This is certainly a surprising finding because the majority of economic sectors were negatively affected by the pandemic. Based on the interview results, there was an increase in online purchases and gifting, mostly done through the medium of delivery. This is what makes the need for various gift places and gifts made from the bamboo increase. Presently, the most ordered products at the Leuwisari bamboo craft center are various types of boxes, trays, and parcel holders.

Meanwhile, the average expenditure of a craftsman per year was IDR 45,380,571, with the highest allocation being $80.3 \%$ for basic needs, such as food, clothing, and shelter. The allocation for health is $7.5 \%$, education is $5.8 \%$, and the remaining $6.4 \%$ is for other needs such as pulses, transportation, and recreation. 
Furthermore, the interview showed that none of the respondents had been negatively impacted economically due to the pandemic. For this reason, the impact factor is eliminated in the analysis of attributes related to the income level of craftsmen. To test it, an analysis was carried out using parametric statistics. In this analysis, the dependent variable $(Y)$ is income, and the independent variable $(X)$ includes age $(x 1)$, marital status $(x 2)$, gender $(x 3)$, education background $(x 4)$, side job ( $x 5)$, working experience $(x 6)$, and the number of the family member $(x 7)$. The correlation equation is as follows:

$$
Y=a+b \times 1+b \times 2+b \times 3+b \times 4+b \times 5+b \times 6+b \times 7+e
$$

Before the correlation regression analysis, a preliminary analysis was carried out, which included tests for normality, homoscedasticity, non-multicollinearity, and non-autocorrelation in determining whether the independent variables used met the requirements analysis. The normality test shows that the data plot is close to the diagonal line, which indicates the variable meets the test requirements, as shown in Figure 4.

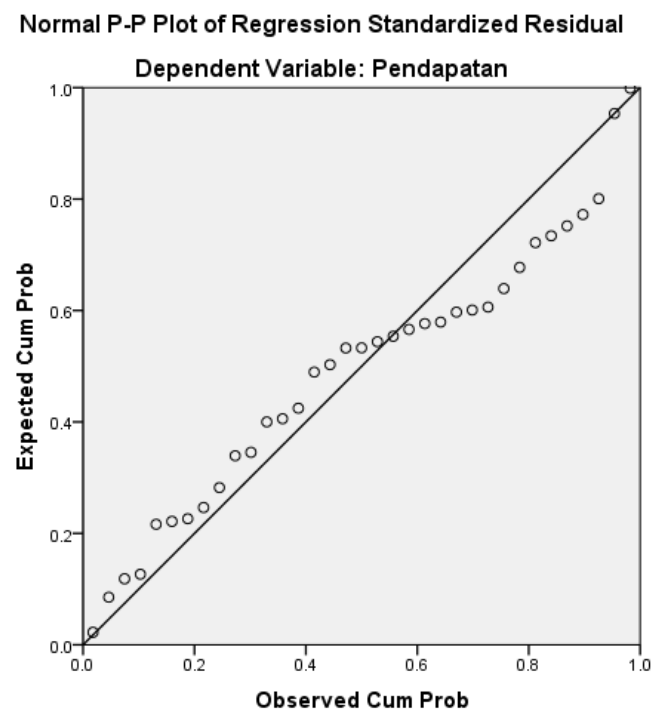

Figure 4. Result of Normality Test

The homoscedasticity test also indicated that the $F$ count of 2.774 was greater than the $F$ table of 2.37 at a 0.05 confidence interval, therefore the assumption of homoscedasticity was met, a shown in Appendix 1. VIF values that are less than 10 also indicate inadequate multicollinearity between variables as a condition for their analysis.

The Durbin-Watson test to determine the relationship between variables was also fulfilled, namely between the range -2 and +2 . Therefore, it is concluded that there is no auto-correlation between variables, as shown in Appendix 2.

After the preliminary test was carried out and all variables met the requirements for the followup, a correlation regression analysis was performed, as shown in Table 1.

Table 1.Analysis of Variance

\begin{tabular}{ll|r|r|r|r} 
Model & $\begin{array}{l}\text { Sum of } \\
\text { Squares }\end{array}$ & Df & Mean Square & F & \multicolumn{1}{c}{ Sig. } \\
\hline Regression & 15727.318 & 7 & 2246.760 & 2.774 & $.026^{\text {b }}$ \\
\hline Residual & 21870.853 & 27 & 810.032 & & \\
\hline Total & 37598.171 & 34 & & & \\
\hline a. & & & & & \\
\hline
\end{tabular}

a. Dependent Variable: Income

b. Predictors: (Constant), Number of Family Member, Age, Side Job, Gender, Marital Status, Education Background, Working Experience 
The analysis of variance showed that the equation is significant at a 95\% confidence interval. However, the model is not strong because it only has an R of 0.647 and an R squared of 0.418 , with a standard error value of 28.46105 . The results of the correlation test between the dependent and independent variables are shown in Table 2.

The table shows that only two factors significantly affect income, namely age and marital status, at the $95 \%$ and $90 \%$ confidence intervals. Both have a positive effect on income, whereby the higher the age, the greater the income, and the married ones have a higher income rate than the unmarried.

Table 4 showed that the age variable has a positive and significant effect on income with a standardized beta coefficient value of 0.604 at the $95 \%$ significance level. These results are in line with the research carried out by Putri \& Setiawina (2013), Ariska \& Prayitno (2019), and Dewi (2012), which stated that age has a significant effect on household income. Age and experience are some of the factors used to measure a person's psychological maturity (Budiono, 2006). Age is an essential factor in supporting one's performance, affecting work productivity (Romansah, 2007). Jayeola et al. (2018), Margaretha \& Supartika (2016), and Keiku et al., (2020) stated that age determines the level of experience, thinking maturity, and the ability of a business actor to determine strategies to win the business competition. An increase in age also affects a person's ability to optimize their experience and potential resources to take advantage of opportunities and face their business challenges (Gimmon et al., 2018; Sukardi, 2011). Furthermore, it is one factor determining the success rate of a business and capable of directly affecting the income level of the business actor. Therefore, based on the research results and several previous studies, the age of the business actor has a strong relationship with income. The more mature a person is, the more significant the positive impact on income level in conducting business.

Table 2. Coefficients Number of Each Variable

\begin{tabular}{|c|c|c|c|c|c|}
\hline \multirow{2}{*}{ Model } & \multicolumn{2}{|c|}{ Unstandardized Coefficients } & \multirow{2}{*}{$\begin{array}{c}\text { Standardized } \\
\text { Coefficients } \\
\text { Beta } \\
\end{array}$} & \multirow{2}{*}{$\mathrm{t}$} & \multirow{2}{*}{ Sig. } \\
\hline & B & Std. Error & & & \\
\hline (Constant) & -28.076 & 51.570 & & -.544 & .591 \\
\hline Age & 1.446 & .570 & .604 & 2.539 & .017 \\
\hline Marital Status & 23.528 & 13.811 & .287 & 1.704 & .100 \\
\hline Gender & -16.490 & 14.330 & -.176 & -1.151 & .260 \\
\hline Education Background & .490 & 2.905 & .033 & .169 & .867 \\
\hline Side Job & 8.702 & 15.699 & .084 & .554 & .584 \\
\hline Working Experience & -.443 & .695 & -.148 & -.638 & .529 \\
\hline Number of Family Member & 2.285 & 6.149 & .059 & .372 & .713 \\
\hline
\end{tabular}

a. Dependent Variable: Income

Apart from age, marital status has a positive and significant relationship with income at a significance value of $90 \%$. The research carried out by Akbariandhini \& Prakoso (2020) and Thasya \& Muhammad (2017) stated that marital status significantly affects a person's income, with married people earning higher than unmarried. Marital status tends to affect a person's motivation to earn income and meet the needs of all family members (Christoper et al., 2019; Hardin, 2019). Therefore, based on this research and preliminary studies, marital status determines the motivation of business actors to increase their income.

\subsection{Impacting Government Regulations to Bamboo-based Industry in Tasikmalaya Regency}

From March 2020 to March 2021, more than 105 regulations related to COVID-19 pandemic responses have been stipulated in national, West Java Province, and DKI Jakarta. The number of regulations increased when combined with lower-level regulations such as regency or municipality levels. The main issue of the pandemic responses is to minimize the spread of the virus. Most of the regulations are related to the strategies used to reduce the people contact, localize the virus, and 
respond to healing those affected by the virus. Response to implementing social distancing is not an issue for the bamboo business, as the artisans tend to work individually in their workshops. However, response related to the travel ban hit the market, especially when it was implemented in Jakarta.

Figures 5 and 6 showed the regulation stipulated by The Central Government, related ministries, the National Taskforce for COVID-19, and provincial governments of DKI Jakarta that affect the bamboo business in Tasikmalaya.

Number of Regulation Related to Transportation and Economic Activity During COVID-19 Pandemic

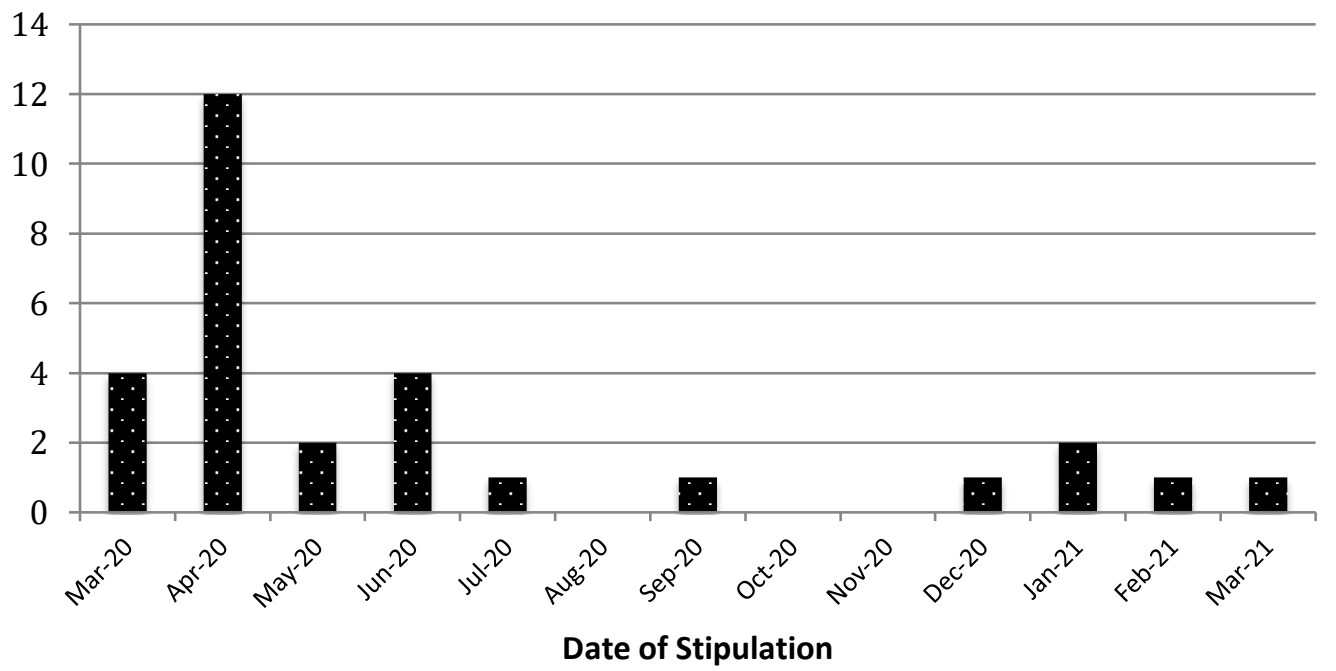

Figure 5. Historical Response Affecting to Bamboo Business in Tasikmalaya

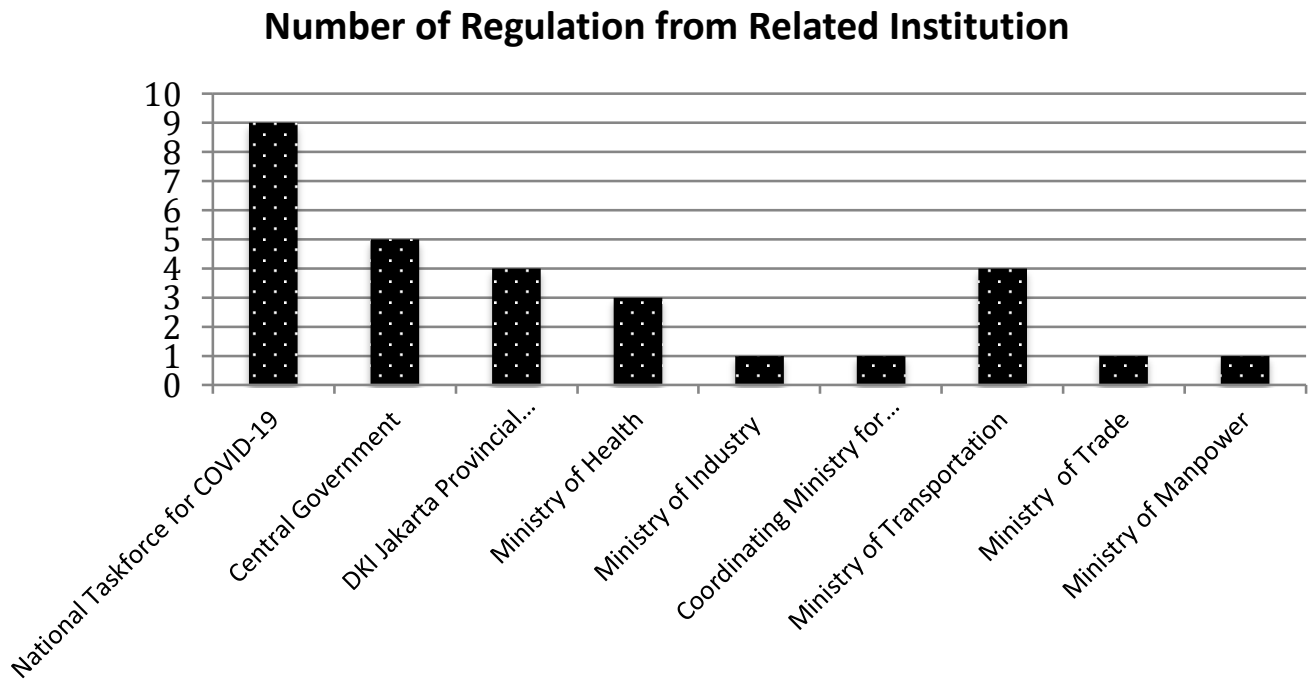

Institution

Figure 6. Regulatory Issuing Institution Affecting Bamboo Business in Tasikmalaya

The Indonesian government reacted by implementing more stringent measures to reduce its spread after the World Health Organization termed the corona virus a global pandemic on $11^{\text {th }}$ March 2020. On $13^{\text {th }}$ March 2021, National Taskforce for COVID-19 was established, which further led to the few regulations that affected the bamboo business in Tasikmalaya. The regulations restrict people's movement, and it directly affected bamboo product transportation. Some checkpoints 
were erected mainly in the borders between regencies. DKI Jakarta province, which has the most significant number of positive cases, was categorized as a black zone. From March to May 2021, the enforcement of transport restrictions was strict.

According to Boone et al., (2020) and Killian et al. (2020), the pandemic hit the business sector hard. Fortunately, the main problem of the bamboo business is only on product transportation to a neighboring province via DKI Jakarta, which is one of the central issues in economic activity (Gray, 2020; Mogaji, 2020). Since April 2020, the Central Government, Ministry of Trade, Ministry of Industry, and Coordinating Ministry of Economic Affair have anticipated the negative impact of the pandemic for the business and economic sectors, which impact on the relaxation of products transportation. From June 2021 to date, transportation is no longer an issue for the bamboo industry in Tasikmalaya.

\subsection{Sustainable Livelihoods Analysis of Bamboo-based Industry in Tasikmalaya Regency}

In terms of the vulnerability context of the bamboo craftsmen, the common source of vulnerability comes from the changing trends. However, the current vulnerability comes from the pandemic effect and the following responses from the government through their regulations. Table 3shows the performance of the artisans' livelihood capitals during the pandemic. The big artisans that provide jobs or orders to the small artisans experienced challenges related to transporting the final products, which affected the physical and financial capital. When the travel ban was lifted, transporting matter was no longer an issue.

Table 3. Five Livelihoods Capitals of Bamboo Artisans During COVID-19 Pandemic

\begin{tabular}{|c|c|c|c|}
\hline Capital & Description & $\begin{array}{l}\text { Impacted by COVID- } \\
19 \text { pandemic and its } \\
\text { response }\end{array}$ & $\begin{array}{l}\text { Strategy to strengthen the } \\
\text { capital }\end{array}$ \\
\hline Human & $\begin{array}{l}\text { - Skillful artisan } \\
\text { - Patience } \\
\text { - Determined to the job }\end{array}$ & No & $\begin{array}{l}\text { Keep accepting new orders. } \\
\text { They make it adequate after } \\
\text { learning to replicate in a day. }\end{array}$ \\
\hline Physical & $\begin{array}{l}\text { - Do not require a decent workshop } \\
\text { - Do not require hi-tech equipment and } \\
\text { tool. } \\
\text { - Work individually in their house. } \\
\text { - Transport service depends on the third } \\
\text { party. }\end{array}$ & $\begin{array}{l}\text { Yes, particularly in } \\
\text { transporting products } \\
\text { to Jakarta }\end{array}$ & $\begin{array}{l}\text { - Cooperate with a travel agent } \\
\text { that keeps providing service } \\
\text { events during travel ban } \\
\text { periods. }\end{array}$ \\
\hline Natural & $\begin{array}{l}\text { - Nearby bamboo forests in Mount } \\
\text { Galunggung Protection Forest Region } \\
\text { - The bamboo forest is healthy and able to } \\
\text { produce the required bamboo pole } \\
\text { specification. No seasonality }\end{array}$ & No & $\begin{array}{l}\text { - Keep maintaining a good } \\
\text { relationship with the bamboo } \\
\text { pole provider }\end{array}$ \\
\hline Social & $\begin{array}{l}\text { - Well-established social } \\
\text { relationship/partnership (gotong royong) }\end{array}$ & No & $\begin{array}{l}\text { - Keep maintaining a good } \\
\text { partnership with the } \\
\text { employer }\end{array}$ \\
\hline Financial & $\begin{array}{l}\text { - The ability of big artisan (employer) to } \\
\text { provide down payment for smaller } \\
\text { artisans (worker) } \\
\text { - The ability of big artisan to maintain } \\
\text { business with buyers outside Tasikmalaya }\end{array}$ & $\begin{array}{l}\text { Yes, particularly } \\
\text { during travel ban } \\
\text { periods. They } \\
\text { allocated more } \\
\text { money for final } \\
\text { product } \\
\text { transportation }\end{array}$ & $\begin{array}{l}\text { - Keep maintaining a good } \\
\text { partnership with the } \\
\text { customers }\end{array}$ \\
\hline
\end{tabular}

\subsection{Why Bamboo Business Remains Exist During the COVID-19 Pandemic?}

The bamboo-based handicraft business has become the main source of livelihood for a significant population in Mandalagiri Village with comparative and competitive advantages. This means that the products produced are not only able to meet the needs of their region, they able have the ability to supply the needs of other regions. 
In general, bamboo raw materials are still relatively easy to obtain by craftsmen because the majority obtains it from suppliers around Tasikmalaya Regency. The origin of this raw material is very important because it is related to the purchasing price. Furthermore, the closer they are to the source of raw materials, the more efficient the cost of supplying raw materials. Generally, the craftsmen do not have difficulties accessing capital because the working relationship between medium and small-scale craftsmen is well established. Medium-scale craftsmen (big artisan) always support capital for the craftsmen that are under the agreement for the product to be paid up to the capital provider. The ease of raw materials, access to capital, and market demand increase the publics' interest in the bamboo handicraft business. This shows that the social capital owned by the associated parties is relatively reasonable and acts as an asset that is less important in encouraging business stability.

Recently, there is an increase in demand for working as a bamboo craftsman by the people of Mandalagiri Village due to its cost-effectiveness and high profits. One type of handicraft product, on average, generates a profit of $50 \%$ of the value of the product, excluding labor. However, this condition shows that working as a bamboo craftsman is more profitable than working outside the region. In addition, $100 \%$ of the respondents stated that the businesses fulfill their monthly needs.

The inception of the COVID-19 pandemic has, directly and indirectly, changed people's lifestyles, especially in densely populated urban areas. People are mandated to stay at home more and avoid crowded areas. The bamboo handicraft products produced by the people of Mandalagiri Village have responded to changes in people's consumption behavior in the new normal era. For example, products were manufactured for people's needs in urban areas used for culinary sales in the pandemic era.

The pandemic is a blessing in disguise for this industry. Moreover, SMEs are more flexible to adapt the new business environment than large firms (Soriano \& Dobon, 2009), and their power of survival is strong (Liñán et al., 2019). The changing pattern of people-to-people communication and relationship also triggered and hastened the development of e-commerce. Supported by social media platforms, distance is no longer an issue. Almost all business activities are carried out on technological gadgets, such as window shopping, placing an order, and paying bills. The bamboo business in Tasikmalaya is capitalizing on this new era, and the products answer the demand of the market, especially the modern market in the cities.This condition was proven during the COVID-19 pandemic with an increase in the demand for bamboo handicrafts. Through the handy artisans, bamboo products remain a market share in this modern era.

\section{Conclusions}

Research related to the impact of the COVID-19 pandemic in Indonesia has not been adequately conducted in aspects of health, tourism, and education, while the impact on small and medium enterprises (SMEs) such as bamboo handicrafts is still limited. Therefore, this research determined the effect of the pandemic on the economic condition of bamboo craftsmen and the influencing factors.

The research showed that the COVID-19 pandemic positively impacted the income of bamboo craftsmen in Mandalagiri Village with an average income increase of $2 \%$ due to demanding factors, availability of raw materials, and public interest in businesses ease of access to capital. However, at Leuwisari, the bamboo handicraft center is still in the category of livelihood activities and has not yet led to micro-enterprises. This indicates a weakness in their ability to determine the type of product and selling price.This research only determines the economic aspect of an increase or decrease in income. Further research is needed to determine the effect of the pandemic on other economic aspects such as employment and also related to efforts to keep the craft business sustainable.For example, through digitalization technology innovation or other efforts to increase performance and contribute to business sustainability and the challenges of socio-economic and cultural behavior faced by handicraft businesses related to the acceptance of these digital technology innovations. Similar research also needs to be carried out in other craft industry centers, such as Bali, Yogyakarta, which are well-known tourist attractions. 
Author Contributions: The first, second, and third authors are the primary authors who conceived the research project and are responsible for the flow and contents of the paper. The rest authors are secondary authors who contribute to deepening the result and discussion part and some part of the research method.

Conflicts of Interest: The authors declare no conflict of interest.

Acknowledgments: The authors are grateful to Mrs. Siti, Mrs. Tri, Mr. Dadih Leo, and Mr. Sirait for their assistance during the data collection process of this independent research.

Appendix 1. Homoscedicity test result

\begin{tabular}{|c|c|c|c|c|c|c|c|}
\hline \multicolumn{8}{|c|}{ Coefficients $^{a}$} \\
\hline \multirow{2}{*}{ Model } & \multicolumn{2}{|c|}{$\begin{array}{l}\text { Unstandardized } \\
\text { Coefficients }\end{array}$} & \multirow{2}{*}{$\begin{array}{c}\text { Standardized } \\
\text { Coefficients } \\
\text { Beta }\end{array}$} & \multirow[t]{2}{*}{$\mathrm{t}$} & \multirow[t]{2}{*}{ Sig. } & \multicolumn{2}{|c|}{ Collinearity Statistics } \\
\hline & B & Std. Error & & & & Tolerance & VIF \\
\hline (Constant) & 18.980 & 54.115 & & .351 & .729 & & \\
\hline Age & 1.446 & .570 & .604 & 2.539 & .017 & .381 & 2.624 \\
\hline Marital Status & -23.528 & 13.811 & -.287 & -1.704 & .100 & .758 & 1.319 \\
\hline Gender & -16.490 & 14.330 & -.176 & -1.151 & .260 & .920 & 1.086 \\
\hline Education Background & .490 & 2.905 & .033 & .169 & .867 & .574 & 1.741 \\
\hline Side Job & 8.702 & 15.699 & .084 & .554 & .584 & .928 & 1.078 \\
\hline Working Experience & -.443 & .695 & -.148 & -.638 & .529 & .402 & 2.486 \\
\hline $\begin{array}{l}\text { Number of Family } \\
\text { Member }\end{array}$ & 2.285 & 6.149 & .059 & .372 & .713 & .858 & 1.166 \\
\hline
\end{tabular}

a. Dependent Variable: Income

Appendix 2. Durbin-Watson test result

\begin{tabular}{r|r|r|r|r|r}
\hline \multirow{2}{*}{ Model } & \multicolumn{2}{|c|}{ R } & \multicolumn{2}{c}{ Rodel Summary } \\
\end{tabular}

a. Predictors: (Constant), Number of Family Member, Age, Side Job, Gender, Marital Status, Education Background, Working Experience

b. Dependent Variable: Income

\section{References}

Abbasov, A., \& Alizada, T. (2016). Small and medium-sized enterprises as an influential factor towards the economic growth of countries with transition economies. Economic and Social Development: Book of Proceedings, 453.

Adil, Z., Sidabutar, H., Susilo, C., \& Justisia, A. (2014). Studi Permintaan Pasar Untuk Produk-Produk Bambu Dan Penilaian Tentang Teknologi-Teknologi Memproses Bambu. Badan Revitalisasi Industri Kehutanan (BRIK).

Akbariandhini, M., \& Prakoso, A. F. (2020). Analisis Faktor Tingkat Pendidikan, Jenis Kelamin, Dan Status Perkawinan Terhadap Pendapatan Di Indonesia Berdasarkan IFLS-5. JPEKA: Jurnal Pendidikan Ekonomi, Manajemen dan Keuangan, 4(1), 13-22.

Ariska, P. E., \& Prayitno, B. (2019). Pengaruh Umur, Lama Kerja, Dan Pendidikan Terhadap Pendapatan Nelayan Di Kawasan Pantai Kenjeran Surabaya Tahun 2018. Economie, 1(1), 3847.

Astuti, S. (2012). Pola Relasi Sosial Petani Dengan Buruh Tani Dalam Produksi Pertanian (Studi Deskriptif Masyarakat Desa Tanjung Rejo, Kecamatan Percut Sei Tuan, Kabupaten Deli Serdang, Sumatera Utara)[Skripsi]. Universitas Sumatera Utara.

Bagherzadeh, M., Markovic, S., \& Bogers, M. (2021). Managing open innovation: A project-level perspective. IEEE Transactions on Engineering Management, 68(1), 301-316. https://doi.org/10.1109/TEM.2019.2949714

Bai, C., Quayson, M., \& Sarkis, J. (2021). COVID-19 pandemic digitization lessons for sustainable development of micro-and small- enterprises. Sustainable Production and Consumption, 27, 1989-2001. doi:10.1016/j.spc.2021.04.035 
Baker, T., \& Judge, K. (2020). How to Help Small Businesses Survive COVID-19. Columbia Law and Economics Working Paper(620).

Barnawi, B. (2020). Eksistensi Home Industri Kerajinan Anyaman Bambu di Heuleut Leuwimunding Majalengka di Era Revolusi Industri 4.0. Etos, 1(1), 34-42.

Bartik, A. W., Bertrand, M., Cullen, Z., Glaeser, E. L., Luca, M., \& Stanton, C. (2020). The impact of COVID-19 on small business outcomes and expectations. Proceedings of the National Academy of Sciences,117(30), 17656-17666..

Bell, J., \& Stellingwerf, J. (2012). Sustainable entrepreneurship: The motivations and challenges of sustainable entrepreneurs in the renewable energy industry [Thesis]. Jönköping International Business School.

Benton, A., Cronin, T., Frith, O., Jonkhart, J., \& Junqi, W. (2011). Market potential of bamboo and rattan products (No. 63). International Bamboo and Rattan Organisation (INBAR).

Bigliardi, B., \& Galati, F. (2016). Which factors hinder the adoption of open innovation in SMEs? Technology Analysis and Strategic Management, 28(8), 869885.https://doi.org/10.1080/09537325.2016.1180353

Boone, L. (2020). Tackling the fallout from COVID-19. In R. Baldwin \& B. W. di Mauro (Eds.), Economics in the Time of COVID-19 (pp. 37-44). CEPR Press.

Bowen, G. A. (2009). Document Analysis as a Qualitative Research Method. Qualitative Research Journal, 9(2), 27-40. https://doi.org/10.3316/QRJ0902027

Budiono, P. R. (2006). Karakteristik Petani Tepi Hutan dan Kompetensinya dalam Pelestarikan Hutan Lindung di 12 Desa di Provinsi Lampung[Disertation]. Institut Pertanian Bogor.

Caballero-Morales, S. O. (2021). Innovation as recovery strategy for SMEs in emerging economies during the COVID-19 pandemic. Research in International Business and Finance, 57, 101396, 1-9. https://doi.org/10.1016/j.ribaf.2021.101396

Christoper, R., Chodijah, R., \& Yunisvita, Y. (2019). Faktor-faktor yang mempengaruhi pendapatan pekerja wanita sebagai Ibu rumah tangga. Jurnal Ekonomi Pembangunan, 15(1), 35-52.

Dai, R., Feng, H., Hu, J., Jin, Q., Li, H., Wang, R., ... \& Zhang, X. (2021). The impact of COVID-19 on small and medium-sized enterprises (SMEs): Evidence from two-wave phone surveys in $\begin{array}{llll}\text { China. China Economic 1-20. } & \end{array}$ https://doi.org/10.1016/j.chieco.2021.101607

Darajat, T. M. (2015). Kajian Industri Kecil Kerajinan Bambu Jawa Barat. Inosains, 10(2), 11.

Department for International Development UK (Producer). (1999). Sustainable Livelihoods Guidance Sheet.

Dewi, P. M. (2012). Partisipasi tenaga kerja perempuan dalam meningkatkan pendapatan keluarga. Jurnal Ekonomi Kuantitatif Terapan. 5(2), 119 - 124.

DfID, U. (1999). Sustainable livelihoods guidance sheets. London: DFID, 445.

Dimson, J., Mladenov, Z., Sharma, R., \& Tadjeddine, K. (2020). COVID-19 and European small and medium-size enterprises: How they are weathering the storm. Retrieved from https://www.mckinsey.com/industries/public-and-social-sector/our-insights/covid-19-andeuropean-small-and-medium-size-enterprises-how-they-are-weathering-the-storm

Directorate General of Disease Prevention and Control. (2020). Coronavirus disease (Covid-19) prevention and control guidelines (fourth revision). Jakarta: Ministry of Health.

Djalante, R., Lassa, J., Setiamarga, D., Sudjatma, A., Indrawan, M., Haryanto, B., . . Rafliana, I. (2020). Review and analysis of current responses to COVID-19 in Indonesia: Period of January to March 2020. Progress in Disaster Science, 6, 100091. https://doi.org/10.1016/j.pdisas.2020.100091

Feranita, N. V., Nugraha, A., \& Sampir, A. S. (2020). Effect of transformational and transactional leadership on SMEs in Indonesia. Problems and Perspectives in Management, 18(3), 415-425. https://doi.org/10.21511/ppm.18(3).2020.34

Forsman, H. (2011). Innovation capacity and innovation development in small enterprises. A comparison between the manufacturing and service sectors. Research Policy, 40, 739-750. https://doi.org/10.1016/j.respol.2011.02.003 
Fusch, P. I., \& Ness, L. R. (2015). Are We There Yet? Data Saturation In Qualitative Research. The Qualitative Report, 20(9), 1408.

Gerring, J. (2008). Case Selection for Case-Study Analysis: Qualitative and Quantitative Techniques. In J. M. Box-Steffensmeier, H. E. Brady, \& D. Collier (Eds.), The Oxford Handbook of Political Methodology (pp. 645-684). Oxford University Press.

Gimmon, E., Yitshaki, R., \& Hantman, S. (2018). Entrepreneurship in the Third Age: Retirees' Motivation and Intentions International Journal of Entrepreneurship and Small Business, 34(3), 267-288. https://doi.org/10.1504/IJESB.2018.10013968

Gray, R. S. (2020). Agriculture, transportation, and the COVID-19 crisis. Canadian Journal of Agricultural Economics/Revue canadienne d'agroeconomie, 68(2), 239-243. https://doi.org/10.1111/cjag.12235

Greiner, R. (2015). Motivations and Attitudes Influence Farmers' Willingness to Participate in Biodiversity Conservation Contracts. Agricultural Systems, 137, 154-165. https://doi.org/10.1016/j.agsy.2015.04.005

Guest, G., Bunce, A., \& Johnson, L. (2006). How Many Interviews Are Enough?: An Experiment with Data Saturation and Variability. Field Methods, 18(1), 59-82. https://doi.org/10.1177/1525822X05279903

Hardin, H. (2019). Identitas Petani Yang Mempengaruhi Pendapatan Bagi Usahatani Padi Sawah Di Kota Baubau. Media Agribisnis, 3(2), 121-144. https://doi.org/10.35326/agribisnis.v3i2.493

Hernández-Espallardo, M., \& Delgado-Ballester, E. (2009). Product innovation in small manufacturers, market orientation and the industrýs five competitive forces: Empirical evidence from Spain. European Journal of Innovation Management, 12(4), 470-491. https://doi.org/10.1108/14601060910996927

Ibrahim, Y. B., \& Nurdian, Y. (2020). Pendampingan Pemasaran Produk Unggulan Anyaman Bambu Antirogo Di Tengah Pandemi. INTEGRITAS: Jurnal Pengabdian, 4(2), 303-311. https://doi.org/10.36841/integritas.v4i2.646

Indexmundi. (2019). Indonesia GDP-Composition by sector. Retrieved 9 May 2020 https://www.indexmundi.com/indonesia/gdp_composition_by_sector.html.

Ingram, J., Gaskell, P., Mills, J., \& Short, C. (2013). Incorporating agri-environment schemes into farm development pathways: A temporal analysis of farmer motivations. Land Use Policy, 31, 267279. https://doi.org/10.1016/j.landusepol.2012.07.007

Jayeola, O., Ihinmoyan, T., \& Kazeem, Y. K. (2018). Environmental Factors and the Performance of Micro and Small Scale Enterprises (MSEs) in Nigeria: Lessons from Some Selected MSEs in Ondo State Nigeria. Journal of Economics, Management and Trade, 2(1), 1-14. https://doi.org/10.9734/JEMT/2018/42079

Keiku, A. N., Harsono, H., \& Hartanto, A. D. (2020). Analisis Pengaruh Modal, Usia, dan Pendidikan Terhadap Pendapatan Pelaku Usaha Skala Mikro (Studi Pedagang Kaki Lima di Kelurahan Gading Kasri, Kota Malang). Journal of Regional Economics Indonesia, 1(1), 48-72. https://doi.org/10.26905/jrei.v1i1.4761

Kencana, M. R. B. (2020). Sri Mulyani Gambarkan Kondisi Ekonomi Indonesia yang Terimbas Virus Corona. Retrieved 18 March 2021 https://www.liputan6.com/bisnis/read/4230078/srimulyani-gambarkan-kondisi-ekonomi-indonesia-yang-terimbas-virus-corona

Killian, J. A., Charpignon, M., Wilder, B., Perrault, A., Tambe, M., \& Majumder, M. S. (2020). Evaluating COVID-19 Lockdown and Business-Sector-Specific Reopening Policies for Three US States. Paper presented at the KDD 2020 Workshop on Humanitarian Mapping. https://doi.org/10.2139/ssrn.3598744

Kirzner, I. M. (2009). The alert and creative entrepreneur: A clarification. Small Business Economics, 32(2), 145-152. doi.org/10.1007/s11187-008-9153-7

Liñán, F., Paul, J. \& Fayolle, A. SMEs and entrepreneurship in the era of globalization: advances and theoretical approaches. Small Business Economics, 695-703. https://doi.org/10.1007/s11187019-00180-7

Liu, C.-W., \& Cheng, J.-S. (2018). Exploring driving forces of innovation in the MSEs: The case of the sustainable B \& B tourism industry. Sustainability, 10, 1-19. doi:10.3390/su10113983 
Lu, L., Peng, J., Wu, J., \& Lu, Y. (2021). Perceived impact of the Covid-19 crisis on SMEs in different industry sectors: Evidence from Sichuan, China. International Journal of Disaster Risk Reduction, 55(24), 1-9. https://doi.org/10.1016/j.ijdrr.2021.102085

Lubis, U. (2008). Pasang Surut Industri Kerajinan Bambu di Tasikmalaya Jawa Karat. Jurnal Dimensi Seni Rupa dan Desain, 5(2), 95-112.

Lutfi, M., Buntuang, P. C. D., \& Hasanuddin, B. (2020). The impact of social distancing policy on small and medium-sized enterprises (SMEs) in Indonesia. Problems and Perspectives in Management, 18(3), 492-503. https://doi.org/10.21511/ppm.18(3).2020.40

Margaretha, F., \& Supartika, N. (2016). Factors affecting profitability of small medium enterprises (SMEs) firm listed in Indonesia Stock Exchange. Journal of Economics, Business and Management, 4(2), 132-137. https://doi.org/10.7763/JOEBM.2016.V4.379

Markovic, S., Koporcic, N., Arslanagic-Kalajdzic, M., Kadic-Maglajlic, S., Bagherzadeh, M., \& Islam, N. (2021). Business-to-business open innovation: COVID-19 lessons for small and medium-sized enterprises from emerging markets. Technological Forecasting and Social Change, 170, 1-5. https://doi.org/10.1016/j.techfore.2021.120883

McKibbin, W., \& Fernando, R. (2020). The Global Macroeconomic Impacts of COVID-19: Seven Scenarios. CAMA Working Paper No. 19. dx.doi.org/10.2139/ssrn.3547729

Ministry of Health. (2020). SE No. HK.02.01/MENKES/202/2020: Protokol Isolasi Diri Sendiri Dalam Penanganan COVID-19.

Mogaji, E. (2020). Impact of COVID-19 on transportation in Lagos, Nigeria. Transportation Research Interdisciplinary Perspectives, 6, 100154. https://doi.org/10.1016/j.trip.2020.100154

Murti, K. A. H. (2018). Kerajinan Anyam Bambu di Sanggar Hamid Jaya Desa Gintangan Kecamatan Rogojampi Kabupaten Banyuwangi. Jurnal Seni Rupa, 6(1), 634-644.

Narula, R. (2020). Policy opportunities and challenges from the COVID-19 pandemic for economies with large informal sectors. Journal of International Business Policy, 3(3), 302-310. https://doi.org/10.1057/s42214-020-00059-5

OECD. (2020). Coronavirus (COVID-19): SME Policy Responses. Retrieved from http://www.oecd.org/coronavirus/en/

Putri, A. D., \& Setiawina, D. (2013). Pengaruh umur, pendidikan, pekerjaan terhadap pendapatan rumah tangga miskin di Desa Bebandem. E-Jurnal Ekonomi Pembangunan Universitas Udayana, 2(4), 173-225.

Roman, M., \& Grudzień, P. (2021). The Essence of Agritourism and Its Profitability during the Coronavirus (COVID-19) Pandemic. Agriculture, 11(5), 458. https://doi.org/10.3390/agriculture11050458

Romansah, D. (2007). Peran Hutan Rakyat dalam Perekonomian Wilayah di Kabupaten Sumedang[Thesis]. Institut Pertanian Bogor.

Rosavina, M., Rahadi, R.A., Kitri, M.L., Nuraeni, S. and Mayangsari, L. (2019). P2P lending adoption by SMEs in Indonesia. Qualitative Research in Financial Markets,11(2), 260-279. https://doi.org/10.1108/QRFM-09-2018-0103

Rosmadi, M. L. N. (2021). Inovasi dan Kreativitas Pelaku Usaha UMKM di Era Covid-19. IKRA-ITH EKONOMIKA, 4(2), 87-94. https://doi.org/10.37817/ikraith-ekonomika.v4i2.1021

Rosyada, M., \& Wigiawati, A. (2020). Strategi Survival UMKM Batik Tulis Pekalongan di Tengah Pandemi Covid-19 (Studi Kasus pada "Batik Pesisir" Pekalongan). BANCO: Jurnal Manajemen dan Perbankan Syariah, 2(2), 69-93. https://doi.org/10.35308/jbkan.v4i2.2424

Sakri, G. (2009). Tinjauan historis perkembangan kerajinan tangan anyaman bambu halus Tasikmalaya. Jurnal Dimensi Seni Rupa dan Desain, 7(1), 127-148.

Setiawan, B. (2010). Strategi Pengembangan Usaha Kerajinan Bambu di Wilayah Kampung Pajeleran Sukahati Kecamatan Cibinong Kabupaten Bogor. Jurnal Manajemen dan Organisasi, 1(2), 135147. https://doi.org/10.29244/jmo.v1i2.14158

Setiawan, S. R. D. (2020). Sebanyak 37.000 UMKM Terdampak Virus Corona. Retrieved 18 March 2020, from Kompas https://money.kompas.com/read/2020/04/17/051200426/sebanyak37.000-umkm-terdampak-virus-corona. 
Simbolon, M. S. T. (2019). Daya Saing Produk Bambu Indonesia di Pasar Internasional [Skripsi]. Institute Pertanian Bogor

Singh, G., \& Belwal, R. (2008). Entrepreneurship and SMEs in Ethiopia: Evaluating the role, prospects and problems faced by women in this emergent sector. Gender in Management: an International Journal, 23(2), 120-136. https://doi.org/10.1108/17542410810858321

Sopandi, E. (2017). Strategi pengembangan usaha kerajinan bambu (Studi di Desa Pasirjambu Kecamatan Pasirjambu Kabupaten Bandung). Jurnal AdBispreneur, 2(1), 1-17. https://doi.org/10.24198/adbispreneur.v2i1.12876

Soriano, D. R., \& Dobon, S. R. (2009). Linking globalization of entrepreneurship in small organizations. Small Business Economics, 32(3), 233-239. doi.org/10.1007/s11187-008-91555

Spence, M., Gherib, J. B. B., \& Biwolé, V. O. (2011). Sustainable entrepreneurship: is entrepreneurial will enough? A north-south comparison. Journal of Business Ethics, 99(3), 335-367. https://doi.org/10.1007/s10551-010-0656-1

Statistic Indonesia of Tasikmalaya Regency. (2020). Kecamatan Leuwisari dalam Angka 2020. Tasikmalaya.

Sugiri, D. (2020). Menyelamatkan usaha mikro, kecil dan menengah dari dampak pandemi Covid-19. Fokus Bisnis: Media Pengkajian Manajemen dan Akuntansi, 19(1), 76-86. https://doi.org/10.32639/fokusbisnis.v19i1.575

Sukardi, S. (2011). Analisis Pengaruh Lama Usaha, Usia dan Pendidikan Terhadap Pendapatan Pengelola Umkm Kabupaten Kulon Progo Yogyakarta. Optimum: Jurnal Ekonomi dan Pembangunan, 1(2), 163-172. dx.doi.org/10.12928/optimum.v1i2.7863

Supriyatno, B. (2020). Dampak Pandemi Covid-19, Ekonomi Indonesia Diperkirakan Pulih 2022. Retrieved 18 March 2021 https://ekonomi.bisnis.com/read/20200427/9/1233454/dampakpandemi-covid-19-ekonomi-indonesia-diperkirakan-pulih-2022

Thasya, M., \& Muhammad, S. (2017). Pengaruh Pendidikan, Umur dan Curahan Jam Kerja Ibu Rumah Tangga Terhadap Pendapatan Keluarga (Studi Kasus: Ibu Rumah Tangga Yang Bekerja Di Industri Batu Bata Di Desa Kajhu Kecamatan Baitussalam). Jurnal IImiah Mahasiswa Ekonomi Pembangunan, 2(1), 105-115. https://doi.org/10.24815/jimekp.v2i1.2465

Tongco, M. D. C. (2007). Purposive sampling as a tool for informant selection. Ethnobotany Research and Applications, 5, 147-158.

Victoria, A. O. (2020). Ekonomi Kuartal I Cuma Tumbuh 2,97\% karena Tiga Sektor Konsumsi Anjlok. Retrieved 18 March 2020 https://katadata.co.id/agungjatmiko/finansial/5eb18fa32eeb4/ekonomi-kuartal-i-cumatumbuh-297-karena-tiga-sektor-konsumsi-anjlok

Wenzel, M., Stanske, S., \& Lieberman, M. B. (2020). Strategic responses to crisis. Strategic Management Journal, 41, V7-V18. https://doi.org/10.1002/smj.3161

Widyaningsih, T. S., Fauziyah, E., \& Kuswantoro, D. P. (2020). Pengolahan dan nilai tambah bambu di Tasikmalaya, Jawa Barat. Jurnal Wasian, 7(1), 51-63. https://doi.org/10.20886/jwas.v7i1.5539

World Health Organization. (2020). WHO Director-General's opening remarks at the media briefing on COVID-19 - 11 March 2020 [Press release]. Retrieved from https://www.who.int/directorgeneral/speeches/detail/who-director-general-s-opening-remarks-at-the-media-briefing-oncovid-19---11-march-2020 